\title{
Pengaruh Pola Penggunaan Otomotif Angkutan Umum Perkotaan Terhadap Hilangnya Kapasitas Baterai Berbahan Lead Acid Secara Prematur
}

\author{
Ahmad Juang Pratama ${ }^{1}$, Hamzah Firdaus ${ }^{2}$ \\ ${ }^{1}$ Program Teknik Industri, ${ }^{2}$ Program Teknik Elektro, Fakultas Sains dan Teknologi \\ Universitas Al Azhar Indonesia, Jl. Sisingamangaraja, Jakarta 12110 \\ ${ }^{1}$ Penulis untuk korespondensi/Email: juang@uai.ac.id
}

\begin{abstract}
Baterai berbahan Lead Acid (BLA) digunakan pada hampir semua kendaraan termasuk angkutan umum beroda empat. Kecepatan penuaan pada proses penuan BLA sangat dipengaruhi oleh cara penggunaan BLA. Pengisian yang berlebihan, akan mengakibatkan korosi dan mempercepat penguapan air. Bertambahannya siklus pembebanan dalam (depth of discharge), degradasi massa postifif akan terakselerasi. Beberapa kerusakan Selain itu pembebanan yang berlebihan juga akan mengakibatkan lepasnya masa positif dari grid karena proses pembebanan BLA yang melebihi seharusnya. Keawetan BLA pada Angkutan umum perkotaan sangat ditentukan pola penggunaannya. Karakteristik operasional yang sering menuntut kendaraan berhenti akan memiliki pengaruh jenis kerusakan tertentu pada komponen BLA Penelitian ini akan mengeksplorasi karakterristikoperasional angkutan perkotaan. Dengan diketahuinya karakteristik operasionalnya maka dapat disiapkan langkah antisipatif dan prediktif dalam hal perawatan dan penggunaan BLA sehingga masa servis BLA akan lebih panjang serta meningkatkan efisiensi biaya para pemilik angkutan perkotaan.
\end{abstract}

Keywords - BLA (Lead Acid Battery), transportasi perkotaan, masa servis BLA

Abstract - Lead Acid batteries (BLA) is used for most of all public transport vehicles including four-wheel drive. Speed of aging battery is strongly influenced by operational pattern and maintenance of public transport vihicle. Overcharging, will result in corrosion and accelerate the evaporation of water. With more loading cycles in the (depth of discharge), positive mass degradation will be accelerated. Moreove, excessive load will also result in the release of a positive mass of the grid due to the excessive load can be taken by battery. The durability of the Battery on urban public transportation is also determined patterns of use. For example, operational characteristics a vehicle that often requires stopping would have the effect of certain types of damage to the components of the battery. This study will explore urban transport operational characteristics. By knowing the operational characteristics, a set of procedures can be set up in order to prevent premature loss of battery capacity. By using apropriate predictive maintenance procedure, the life span of battery will be longer, thus will improve the cost efficiency for starter lead acid battery replacement.

Keywords - BLA (Lead Acid Battery), urban transport, service life BLA

\section{PENDAHULUAN}

Latar Belakang

Baterai berbahan Lead Acid (BLA) digunakan pada hampir semua kendaraan termasuk angkutan umum beroda empat. Seiring dengan kenaikan harga BBM, pemilik angkutan umum juga dibebani oleh kebutuhan penggantian BLA. BLA yang digunakan oleh Angkutan perkotaan adalah berjenis SLI (start, lighting, ignition) sama dengan yang digunakan oleh kendaraan pribadi. Selama ini karena jenis mobil yang sama, jarang dibedakan aplikasi BLA pada angkutan umum dan kendaraan 
pribadi, padahal walaupun jenis berjenis sama, karakteristik pemakaian yang berbeda akan mempengaruhi panjangnya masa servis BLA.

Kecepatan penuaan pada proses penuan BLA sangat dipengaruhi oleh cara penggunaan BLA [2]. Pengisian yang berlebihan, akan mengakibatkan korosi dan mempercepat penguapan air. Bertambahannya siklus pembebanan dalam (depth of discharge), degradasi massa postifif akan terakselerasi. Beberapa kerusakan Selain itu pembebanan yang berlebihan juga akan mengakibatkan lepasnya masa positif dari grid karena proses pembebanan BLA yang melebihi seharusnya.

Setiap bidang aplikasi lead acid memiliki kecendrungan kehilangan kapasitas secara prematur yang disebabkan oleh salah satu jenis kerusakan dominan yang disebabkab pola penggunaan yang hampir sama [2]. Keawetan BLA pada Angkutan umum perkotaan sangat ditentukan pola penggunaannya. Karakteristik operasional yang sering menuntut kendaraan berhenti akan memiliki pengaruh jenis kerusakan tertentu pada komponen BLA Penelitian ini akan mengeksplorasi lebih dalam karakterristil operasional angkutan perkotaan. Dengan diketahuinya karakteristik operasionalnya maka dapat disiapkan langkah antisipatif dan prediktif dalam hal perawatan dan penggunaan BLA sehingga masa servis BLA akan lebih panjang serta meningkatkan efisiensi biaya para pemilik angkutan perkotaan.

\section{Tujuan}

1. Tujuan penelitian ini adalah meneliti varibelvariabel pola penggunaan otomotif angkutan umum yang akan menyebabkan BLA kehilangan kapasitasnya secara prematur

2. Merekomendasikan langkah-langkah Prediktif maintenance bagi pengemudi dan pemilik angkutan umum perkotaan.

\section{Perumusan Masalah}

Adapun permasalahan yang ingin dibahas adalah merangkum pola penggunaan yang tidak tepat sehingga mempercepat berkurangnya masa servis BLA pada mobil angkutan umum beserta tindakan koreksi untuk mengatasi permasalahan tersebut.

\section{Ruang Lingkup}

Penelitian dilakukan dengan melakukan survey pola penggunaan dan perawatan BLA pada pengemudi angkutan umum perkotaan di Jakarta selatan. Adapun populasi yang dipilih pada mobil-mobil yang berusia antara 1-3 tahun.

\section{KERANGKA TEORI}

\section{Proses pada pengecasan dan pembebanan baterai}

BLA menggunakan anode berbahan timbal $(\mathrm{Pb})$ dan katode berbahan timbal dioksida $\left(\mathrm{PbO}_{2}\right)$, $\mathrm{H}_{2} \mathrm{SO}_{4}$, dan separator diantara 2 elektroda. Reaksi kimia yang terjadi pada elektroda positif dan elektroda negatif pada baterai adalah sebagai berikut:

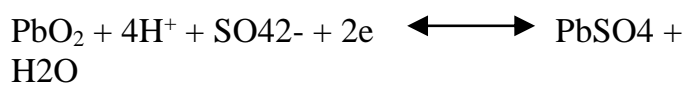

(Elektroda positif)

$\mathrm{Pb}+\mathrm{SO} 42-\quad \longleftrightarrow \quad \mathrm{PbSO} 4+2 \mathrm{e}-$

(Elektroda positif)

Berdasarkan reaksi diatas $\mathrm{PbSo} 4$ akan terbentuk pada elektroda positif dan elektroda negatif selama proses pembebanan / penggunaan baterai. Sementara pada proses pengecasan $\mathrm{PbSO} 4$ akan terurai dan elektroda menjadi $\mathrm{Pb}, \mathrm{PbO} 2$ dan $\mathrm{H} 2 \mathrm{SO} 4$.

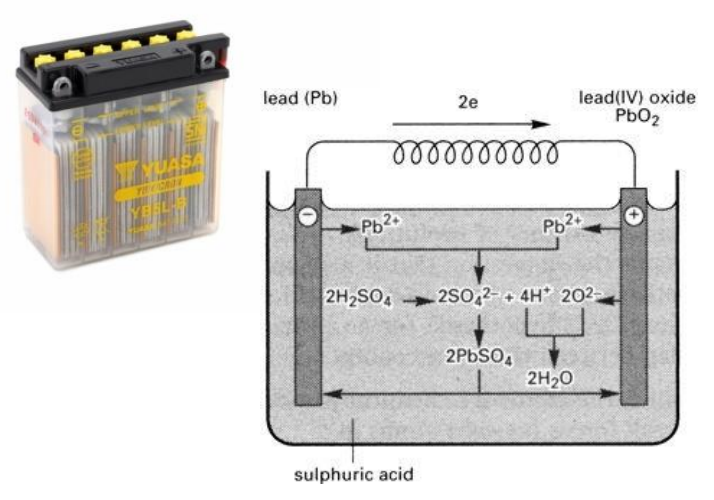

Gambar 1. Baterai Lead Acid dan reaksi elektroda

Reaksi elektrolisis ini bersifat reversibel dan seharusnya berjalan terus menerus [3]. Tetapi pada kenyataannya dengan berjalannya siklus pengisian dan pembebanan BLA, ada titik tertentu dimana arus berhenti mengalir walaupun telah diberikan tegangan. Hal ini diakibatkan oleh bertambahnya hambatan dalam (Internal resistance). Lebih singkatnya, 
BLA tidak dapat lagi memiliki kapasitas penyimpanan.

\section{Mekanisme Penuaan dan Berakhirnya masa servis pada BLA}

Pada BLA, mekanisme penuaan yang secara bertahap mengakhiri masa servis aki umumnya terdiri dari. Korosi Anodic, Degradasi massa positif dan lepasnya massa dari grid, Tidak terurainya $\mathrm{PbSO} 4$ yang membentuk kristal pada massa aktif elektroda, Kekurangan air, Hubungan Singkat [2]

Mekanisme penuaan sering saling berkaitan, sebagai contoh korosi pada grid akan mengakibatkan bertambahnya hambatan pengantar arus yang mengakibatkan panas dan memicu pembentukan kristal timbal sulfat. Peluruhan massa aktif juga mengakibatkan hubungan singkat [2]. Sementara senyawa sulfat juga berlubungan dengan menguapnya air.

Kecepatan penuaan ini dipicu oleh berbagai jenis dan kondisi penggunaan. Overcharge akan menyebabkan korosi dan mempercapat keringnya air, sementara kesalahan penggunaan dengan pada deep of discharge bisa menyebabkan hubungan singkat yang disebabkan oleh pembentukan metallic lead dendrite. Selain itu penggunaan yang berbeda akan memberikan pengaruh pada mikrostuktur elektrode BLA [3], misalnya pada kondisi bus kota akan terjadi peluruhan massa pada grid karena frekuensi pemberhentian yang lebih sering. Sementara pada BLA berjenis VRLA (maintenance free) sering ditemukan korosi pada plat negatif dan kekurangan air.

\section{Sulfatisasi}

Hal yang menjadi faktor utama dari peningkatan internal resistance ini adalah sulfatisasi yang disebabkan oleh adanya kristalisasi dari $\mathrm{PbSO}_{4}$ selama proses pembebanan BLA [4]. Pada proses pengisian $\mathrm{BLA}, \mathrm{PbSO}_{4}$ akan diurai menjadi ion $\mathrm{Pb}^{2+}$ dan $\mathrm{SO}_{4}{ }^{2-}$, pada kenyataannya ada timbal sulfat yang tidak terurai dan membentuk kristal dan menempel pada elektroda. Dengan berulangnya siklus pengisian dan pembebanan kristal ini secara bertahap menutupi dan menyumbat rongga pada elektroda yang memperkecil area kontak dengan $\mathrm{H} 2 \mathrm{SO} 4$.

\section{Kapasitas BLA dan Hukum Peukert}

Pengertian kapasitas baterai mengacu pada jumlah energi yang dapat disimpan baterai. Produsen BLA sering menggunakan spesifikasi yang dikenal sebagai Amp Hour untuk memberikan indikasi kapasitas baterai yang tersimpan. Tetapi kapasitas BLA akan ditentukan oleh besarnya arus pembebanan. Artinya semakin besar pembebenan pada BLA semakin kecil pula kapasitas BLA. Fenomena ini disebut sebagai hukum Peukert.

\section{Jenis-jenis BLA}

Berdasarkan penerapannya, BLA dapat dibagi menjadi beberapa tipe [1]:

1. SLI (start, lighting, Ignition) yang digunakan pada otomotif

2. Stationary untuk mendukung catu daya untuk menghasilkan dan menyimpan energi listrik. ; yang digunakan pada sistem telekomunikasi, pusat utilitas listrik, dan sistem komputer.

3. Traksi untuk sumber tenaga peralatan transportasi seperti fork-lift, mobil listrik, dan perlengkapan pertambangan

4. Baterai khusus yang dimaksudkan untuk penggunaan pesawat terbang, kapal selam dan peralatan militer.

\section{Daya Starter \\ Dunia industri menggunakan standar daya starter otomotif dengan ukuran CCA (Cold cranking Apms). Standar ini menunjukkan kemampuan BLA memberikan arus pada suhu - $18^{\circ} \mathrm{C}$ selama 30 detik. Sementara bisa bertahan pada voltase 1,2 volt per sel BLA atau lebih tinggi.}

\section{Depth of Discharge}

Depth of Discharge (DOD) digunakan untuk menunjukkan berapa dalam pembebanan pada suatu Baterai, Jika baterai $100 \%$ penuh maka DOD dari baterai tersebuat adalah 0\%, Jika baterai menggunakan $30 \%$ dari energinya dimana masih $70 \%$ tersimpan maka dapat dikatakan baterai ini memiliki DOD $30 \%$.

\section{METODOLOGI PENELITIAN}

\section{Langkah Penelitian}

Penelitian ini dimulai dengan studi literatur tentang penyebab BLA kehilangan kapasitas secara prematur serta observasi awal dilapangan, yang dilanjutkan pembuatan dan 
penyebaran quesioner untuk mengetahui pola penggunaan kendaraan terutama yang berhubungan dengan daya starter BLA pada kendaraan angkutan umum perkotaan. Pada Kuesioner dilakukan uji validitas dan reliabilitas, penyebaran quesioner dilakukan secara random dengan pada responden. Berdasarkan hasil quesioner dianalisa faktorfaktor pola pemakaian yang berkontribusi terhadap hilangnya kapasitas BLA secara prematur. Dengan demikian diharapkan akar permasalahan dapat di temukan, dan rekomendasi tindakan koreksi dapat diusulkan, sehingga dapat bermanfaat bagi para pemilik/supir angkot serta masyarakat pada umumnya. Selain itu juga dianalisa perspektif kepuaan terhadap merk BLA dengan menggunakan skala Likert [5].

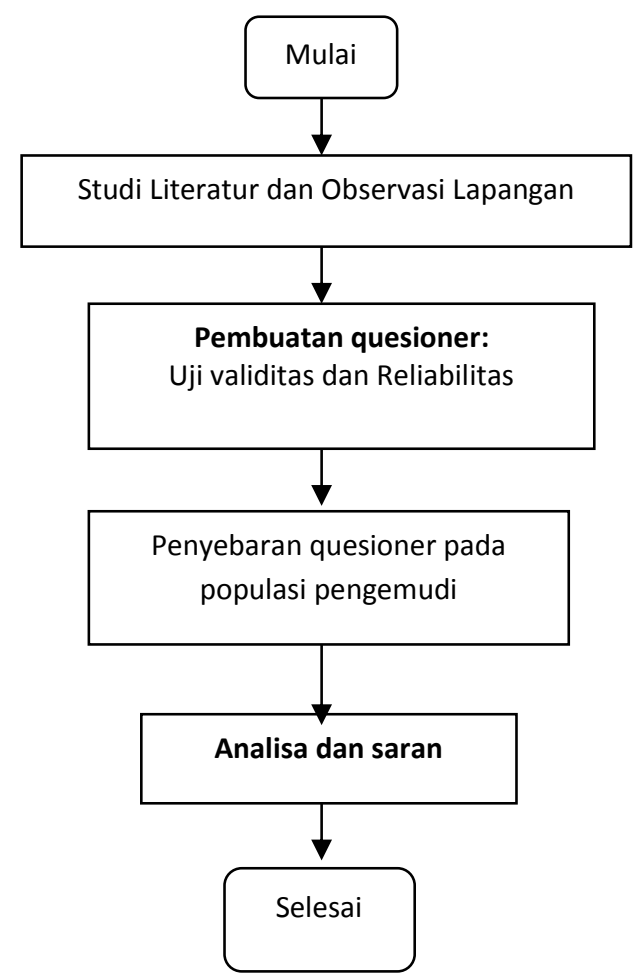

Gambar 2. Metodologi penelitian

\section{Data dan Sumber Data}

Data:

1. Wawancara dengan pengemudi /pemilik kendaraan,

2. Wawancara dengan montir

3. BLA pada kendaraan

Sumber Data:

1. Quesioner

2. Spesifikasiprodusen BLA

\section{HASIL DAN PEMBAHASAN}

\section{Lokasi dan Waktu Kegiatan}

Kegiatan dilaksanakan disekitar daerah petukangan Selatan Jakarta Selatan, sedangkan waktu pelaksanaan kegiatan mengacu pada tabel waktu yang ditetapkan pada proposal, dimana terdapat trayek angkutan perkotaan yang diamati yaitu jalur lebak-bulus Petukangan sejauh $14 \mathrm{Km}$.

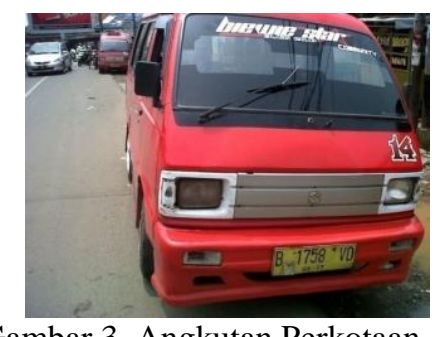

\section{Tahapan Penelitian}

\section{Observasi lapangan}

Observasi dipalangan dimaksudkan sebagai upaya untuk mendapatkan data awal yang berkaitan dengan jenis kendaraan, jenis BLA (Accu/Baterai Lead Acid), dan Kondisi pemakaian. Serta mengetahui factor-faktor apa saja yang mempengaruhi umur pakai BLA pada angkutan.

\section{Jenis kendaraan}

Jenis kendaraan yang diamati adalah jenis kendaraan yang berusia diatas 3 tahun yang berdaya angkut 11-12 orang berdasarkan peraturan dinas perhubungan, hal ini dikarenakan BLA yang mengalami penuaan awal lebih sering terjadi pada mobil-mobil yang berusia diatas 3 tahun. Pada lokasi yang yang diambil, jenis kendaraan yang paling banyak digunakan adalah Suzuki carry 1000 $1300 \mathrm{cc}$.

\section{Jenis BLA}

Jenis BLA yang paling banyak digunakan adalah jenis Aki Basah. Aki basah lebih banyak digunakan karena lebih murah jika dibanding yang berjenis maintenance free. Sedangkan spesifikasi yang digunakan adalah NS 40 (32 AH), dan NS 60 (45 AH). 


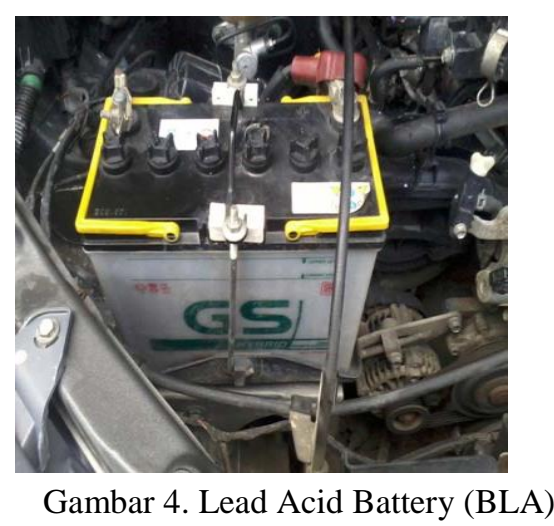

Kondisi pemakaian dan masa pakai BLA

Secara umum, Angkot beroperasi dari jam 04.30 pagi sampai 09.00 malam, dengan jarak trayek $14 \mathrm{KM}$. Dengan maksimal 2 shift supir bergantian. Dari wawancara temukan bahwa masa pakai BLA rata-rata berkisar 6-12 bulan bergantung pada kondisi operasional dan perawatan.

Selain itu Berdasarkan studi literatur tentang mekanisme penuaan pada BLA, diamati polapola pemakainan seperti apa yang berkontribusi terhadap berakhirnya masa Pakai BLA, seperti yang didapat pada studi literatur. Korosi Anodic, Degradasi massa positif dan lepasnya massa dari grid, Tidak terurainya $\mathrm{PbSO} 4$ yang membentuk kristal pada massa aktif elektroda, Kekurangan air, Hubungan Singkat [2].

Pada tabel dibawah terlihat beberapa pola penggunaan kendaraan memicu satu atau beberapa jenis mekanisme penuaan pada BLA, yang akan memperpendek umur pakai pada BLA. Selain itu, seperti yang dibahas pada studi literature, mekanisme penuaan sering saling berkaitan, sebagai contoh korosi pada grid akan mengakibatkan bertambahnya hambatan pengantar arus yang mengakibatkan panas dan memicu pembentukan kristal timbal sulfat. Peluruhan massa aktif juga mengakibatkan hubungan singkat [2]. Sementara senyawa sulfat juga berlubungan dengan menguapnya air.
Tabel 1 Faktor-faktor Pemicu Penuaan BLA

\begin{tabular}{|c|c|c|c|}
\hline No & Mekanisme & Penyebab & $\begin{array}{c}\text { Pemicu pada } \\
\text { pola } \\
\text { penggunaan } \\
\text { dan perawatan } \\
\text { kendaraan }\end{array}$ \\
\hline 1 & $\begin{array}{l}\text { Korosi } \\
\text { Anodic }\end{array}$ & Overcharge & $\begin{array}{l}\text { Charging } \\
\text { yang } \\
\text { dipaksakan }\end{array}$ \\
\hline 2 & $\begin{array}{l}\text { Lepasnya } \\
\text { Massa } \\
\text { Positiv } \\
\text { dari Grid }\end{array}$ & $\begin{array}{l}\text { Frekuensi } \\
\text { Discharge }\end{array}$ & $\begin{array}{ll}\text { - } & \text { Frekuensi } \\
& \text { Pemberhent } \\
\text { ian Trayek } \\
\text { - } & \text { Modifikasi } \\
\text { Sound } \\
\text { system } \\
\text { - } & \text { Mesin Sulit } \\
\text { distarter } \\
\text { ketika } \\
\text { dingin } \\
\text { - } & \text { Masalah } \\
\text { Kelistrikan } \\
\text { Mobil }\end{array}$ \\
\hline 3 & $\begin{array}{l}\text { Tidak } \\
\text { terurainya } \\
\text { PbSO4 }\end{array}$ & $\begin{array}{l}\text { Kurangnya } \\
\text { air, } \\
\text { Overcharge }\end{array}$ & $\begin{array}{l}\text { - Pengecekan } \\
\text { air yang } \\
\text { tidak teratur }\end{array}$ \\
\hline 4 & $\begin{array}{l}\text { Hubungan } \\
\text { Singkat }\end{array}$ & $\begin{array}{l}\text { Pembebanan } \\
\text { berlebih }\end{array}$ & $\begin{array}{ll}\text { - } & \text { Modifikasi } \\
\text { sound } \\
\text { system dan } \\
\text { Lampu } \\
\text { mobil } \\
\text { - } & \text { Masalah } \\
\text { Pada } \\
\text { Kelistrikan } \\
\text { mobil } \\
\text { - Mesin sulit } \\
\text { distarter } \\
\text { ketika } \\
\text { dingin }\end{array}$ \\
\hline
\end{tabular}

Pada dasarnya penyebab mekanisme penuaan pada BLA berdasarkan observasi di lapangan dibagi menjadi 2 parameter utama 
1. Pola Perawatan

Umur BLA secara langsung berkaitan dengan faktor pengecekan kelistrikan dan factor pengecekan ketinggian air. Sementara itu faktor perawatan mesin juga memiliki pengaruh, sebab sering ditemui ketika mesin dalam dingin kendaraan akan sulit dihidupkan, ini akan mengakibatkan beban BLA akan bertambah berat.

\section{Pola Pemakaian}

Pola pemakaian yang mempengaruhi umur pakai BLA diantaranya penggunaan BLA yang tidak disesuaikan dengan pemakaian, seringkali pemilik angkot melakukan modifikasi sound system dan lampu tanpa melakukan penyesuaian spesifikasi BLA. Pada saat mesin dingin yang sulit hidup proses starting terlalu lama dan berkali-kali dengan jeda waktu yang singkat. Frekuensi pemberhentian juga akan berpengaruh pada usia BLA, Ketika BLA sdh mulai lemah, charging dilakukan dengan terlalu cepat.

\section{Pembuatan Quesioner dan Pengambilan data}

Pembuatan Quesioner dilakkukan untuk mengetahui dan menguji faktor-faktor dominan yang menyebabkan pendeknya usia pemakaian BLA. Selain itu mengetahui tingkat kepuasan terhadap kualitas aki merek-merek tertentu, berdasarkan kala Likert [5], untuk menjaga kerahasiaan maka merek tersebut akan menggunakan inisial A, B, C. Dengan mengambil sample pada Trayek angkot KWK s14. Dengan jumlah sampel hanya sebanyak 40 angkot, yang diambil secara acak. Dengan demikian berdasarkan jumlah sampel, hasil ini tidak dapat dikatakan mewakili populasi yang ada. Namun paling tidak hasil penelitian ini dapat menggambarkan keadaan yang sesungguhnya secara garis besar.

\section{Pengambilan data}

Agar pengambilan kuesioner tepat sasaran, maka berdasarkan data hanya mobil yang berusia 3 tahun keatas pada saat penelitian ini dilakukan yang diambil sebagai sumber data, selain itu merk kendaraan adalah suzuki carry 1.000 cc sampai 1300 cc yang dipakai pada trayek s14 lebak bulus-petukangan utara.

\section{Pola perawatan}

Pada umumnya pengecekan mesin dilakukan cukup baik terutama pada kendaraan dengan kepemilikan sendiri. Sebanyak $45 \%$ responden melakukan perawatan mesin sebulan sekali, $27 \% 3$ bulan sekali, sementara $28 \%$ menjawab lain-lain. Dari $28 \%$ ini ada yang menyatakan bahwa perawatan mesin ini disesuaikan dengan kebutuhan, sebagian menjawab karena kendaraan bukanlah milik sendiri hanya sebagai supir, sehingga perawatan diserahkan kepada pemilik.

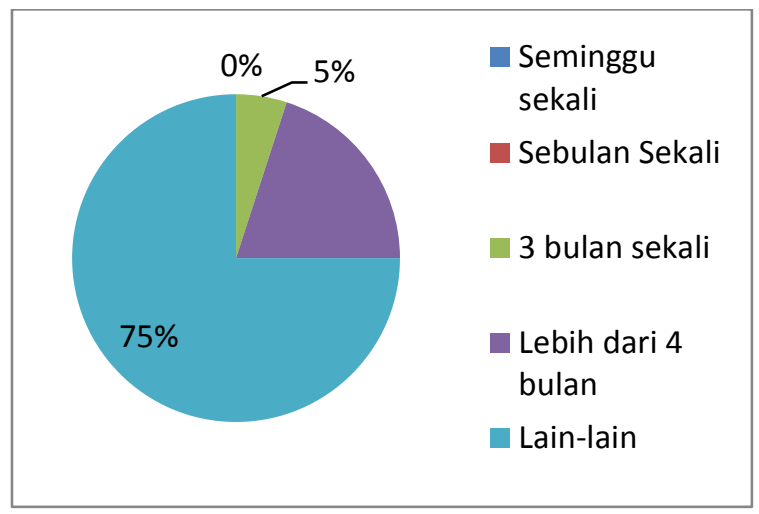

Gambar 5. Frekuensi perawatan mesin

Pada Pengecekan air aki, mayoritas responden mekalukan pengecekan paling tidak sebulan sekali 58\%, sementara sebagian kecil melakukan pengecekan seminggu sekali $12 \%$, dan sebagian menjawab sesuai kebutuhan $30 \%$

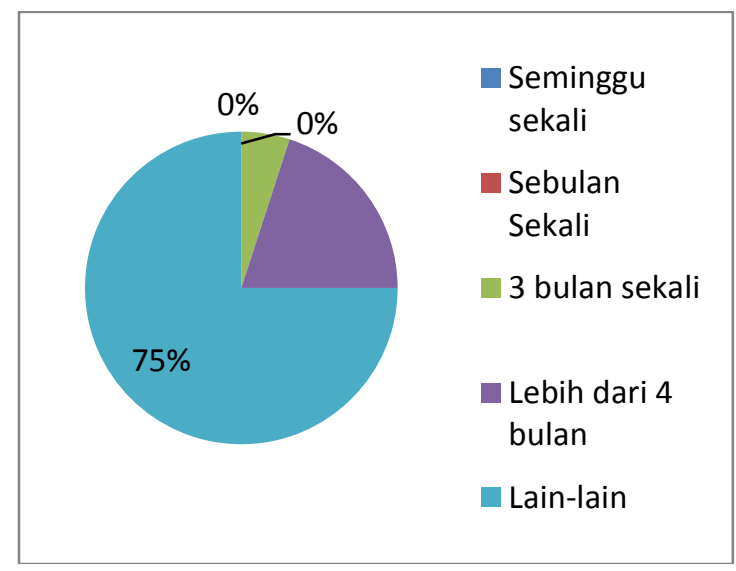

Gambar 6. Frekuensi Pengecekan air Aki

Pengecekan kelistrikan agaknya merupakan sesuatu yang kurang diperhatikan, hal ini terlihat dari hasil quesioner $75 \%$ menyatakan sesuai kebutuhan, $20 \%$ setelah 4 bulan, dan $5 \%$ responden 3 bulan sekali. 


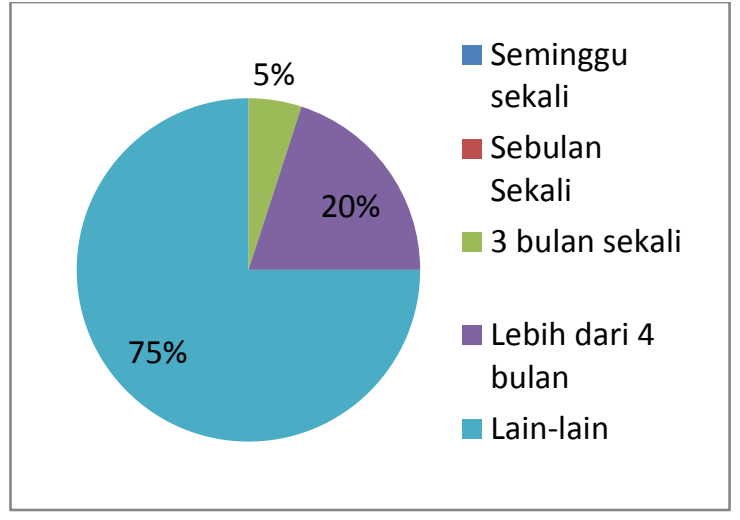

Gambar 7. Frekuensi Pengecekan Kelistrikan

\section{Pola Pemakaian}

Jumlah trayek pulang-perdi trayek dalam satu hari, sebanyak 18\% 6-8 kali, 12,30\% 9-10 kali 1 hari, 6,15\% sampai 5 kali pp sehari, semenstara 4,1\% menjawab lain-lain. Dari data ini terlihat jelas bahwa dibanding mobil pribadi frekuensi pemakaian kendaraan jauh berbeda.

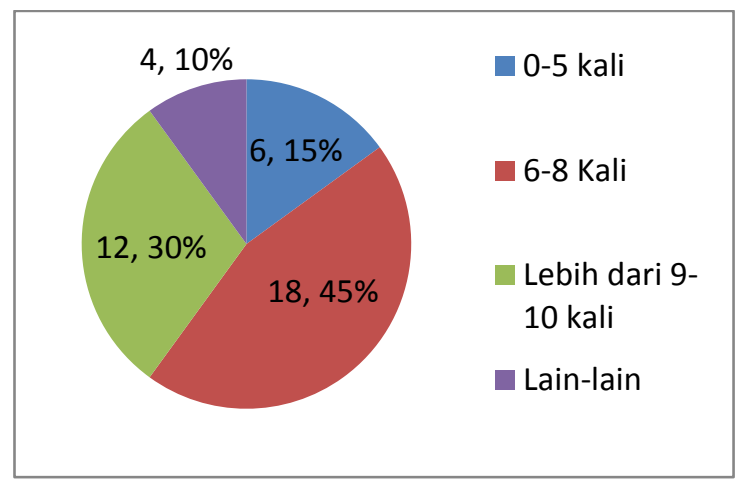

Gambar 8. jumlah PP rute per hari

Pada jumlah starter yang diperlukan untuk menghidupkan mesin dingin, 35\% menjawab 12 kali, 35\% lainnya lebih dari 3 kali, dan 30\% menjawab lain-lain.

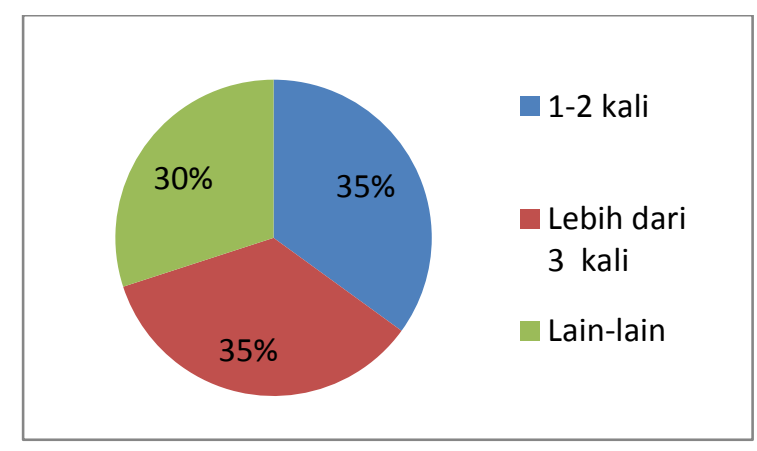

Gambar 9. Jumlah starter untuk menghidupkan mesin dingin
Pada frekuensi penghidupan dan mematikan $78 \%$ menjawab diatas $15 \mathrm{kali}$, sementara $22 \%$ menjawab 10- 15 kali. Tingginya frekuensi hidup mati ini terjadi terutama pada pemberhentian diterminal dimana kendaraan antri untuk mendapatkan penumpang.

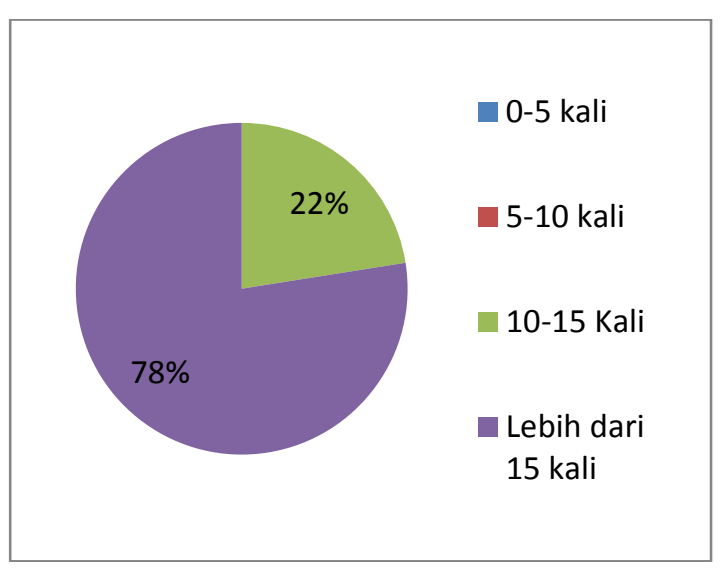

Gambar 11. frekuensi hidup mati kendaraan

Pada 9 responden yang menambahkan sound sistem, $78 \%$ diantaranya meng Up-Grade akinya sementara $22 \%$ tetap menggunakan aki standar.

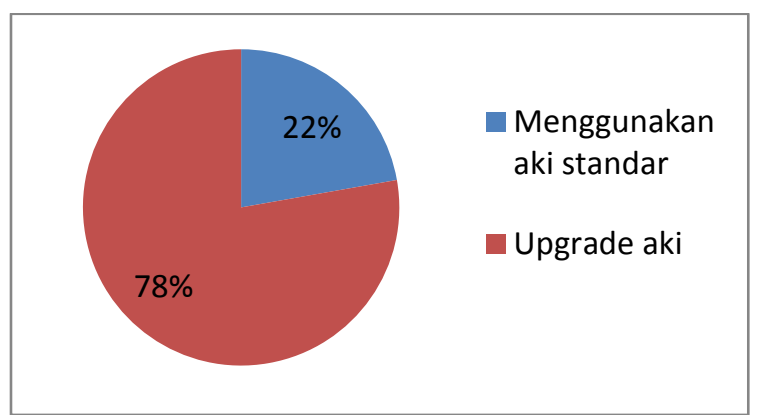

Gambar 12. Persentase yang meng "Up-Grade" BLA

\section{Persepsi kepuasan terhadap kualitas BLA}

Persepsi kepuasan kualitas BLA pada Ampere Hour yang sama, sangat berkaitan dengan merek, untuk menjaga kerahasiaan merk dengan inisial A,B,C, dan D. Sebagai contoh pemakai BLA merek $\mathrm{B}$ cenderung memiliki tingkat kepuasan diatas BLA Merk A. Walaupun rata-rata responden mengaku merasa kurang puas terhadap merk A dab B.

Pada BLA A yang menyatakan cukup puas hanya $15 \%$, smentara yang tidak puas $62 \%$, sebesar $23 \%$ menyatakan sangat tidak puas. 


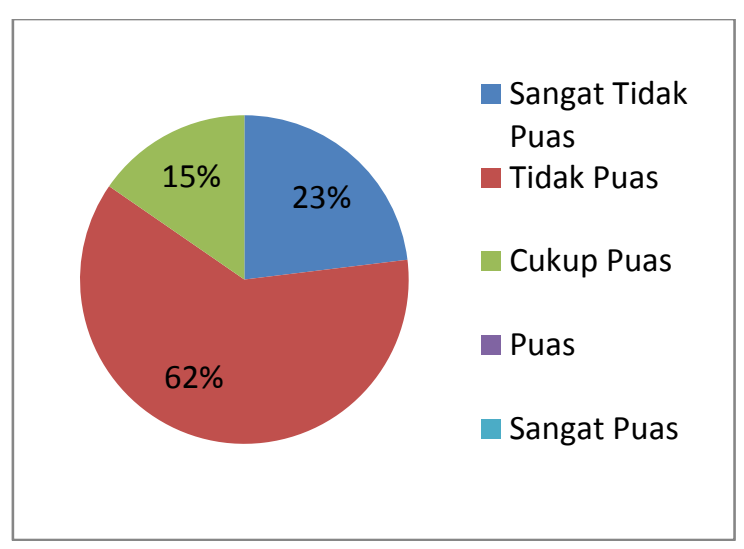

Gambar 13. Kepuasan terhadap Umur Pakai Aki Merk A

Pada BLA Merk B, yang menyatakan cukup puas sebesar $31 \%$, sementara yang menyatakan tidak puas $56 \%$, sedangkan yang menyatakan sangat tidak puas sebesar $13 \%$.

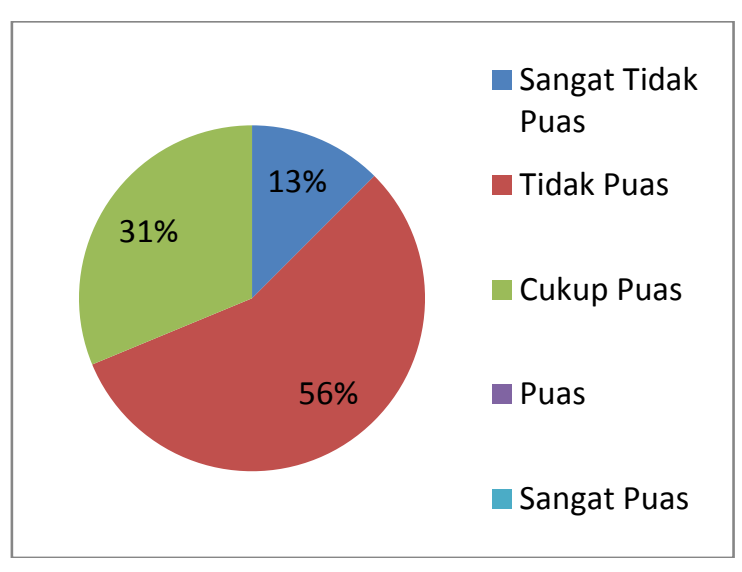

Gambar 14. Kepuasan terhadap Umur Pakai Aki Merk B

\section{Pembahasan}

\section{Pola Perawatan}

Pola perawatan mesin pada dasarnya sudah cukup baik hal ini dapat dilihat $45 \%$ responden melakukan perawatan mesin sebulan sekali. Sementara kebanyakan responden kurang memperhatikan perawatan BLA. Hal ini dapat dilihat dari frekuensi pengecekan air aki dimana hanya $12 \%$ yang melakukan pengecekan level air aki seminggu sekali. Level air aki yang rendah mengakibatkan $\mathrm{PbSO} 4$ (timbal sulfat) tidak dapat terurai dengan baik yang pada gilirannya akan menyebabkan sulfatisasi lebih banyak. Pengecekan aki ini sangat penting mengingat kondisi operasional Angkot lebih berat dibanding pemakaian normal, dan ruangan terbuka sepanjang hari.
Kondisi ini mengakibatkan penguapan air pada BLA lebih cepat. Pengecekan masalah kelistrikan juga harus lebih sering dilakukan, hal ini dapat dilihat dari jawaban responden yang sebesar $75 \%$ mengatakan pengecekan kelistrikan hanya dilakukan sesuai kebutuhan. Permasalahan kelistrikan akan memicu lepasnya Massa positif dari Grid, selain itu juga akan merangsang terjadinya sulfatisasi hal ini dikarenakan BLA akan bekerja lebih keras dan akibatnya akan memambah panas, yang mempercepat penguapan air.

\section{Pola Pemakaian}

Secara umum kondisi pemakaian Angkot jauh lebih ekstrim jika dibandingkan kendaraan pribadi dan oprerasional perusahaan. Sebagai contoh minimal 5 kali pp sehari, sementara 4,1\% sampai 9-10 kali perhari. Kondisi ini adalah kondisi yang mau tidak mau harus diterima. Tetapi untuk memperpanjang usia aki, supir angkot dapat mengurangi sebisa mungkin frekuensi hidup mati mesin sepanjang tidak diperlukan. Dimana 33\% responden memiliki frekuensi hidup mati sebesar 10-15 kali perhari. Pada kondisi mesin dingin pola starter yang baik ada 1-2 kali, jika lebih dari itu maka harus dilakukan pengecekan air aki dan mesin, mengingat kedua hal tersebut saling berhubungan menyebabkan lepasnya massa positif dari grid dan mempercepat sulfatisasi. Jika ada modifikasi sound system dan lampu untuk entertainment penumpang harus dilakukan penyesuaian muatan aki, dalam survey masih ada $22 \%$ responden yang hanya menggunakan kapasitas BLA standard walaupun sudah membutuhkan daya yang lebih.

\section{Persepsi Kepuasan terhadap kualitas BLA}

Berdasarkan data yang didapat, sebagian besar responden kurang puas terhadap BLA yang beredar di pasaran, Pada BLA merk A dan B masing-masing sebesar $62 \%$ dan $52 \%$ menyatakan tidak puas terhadap kualitas aki yang mereka gunakan. Dengan demikian produsen BLA perlu mendesain ulang BLA untuk segmen angkutan umum, hal ini wajar mengingat kondisi lapangan BLA angkutan umum bebannya lebih berat dibanding dengan kendaraan pribadi atau operasional pada umumnya. 


\section{KESIMPULAN DAN SARAN}

\section{Kesimpulan}

Berdasarkan observasi dilapangan serta pengambilan data didapatkan faktor-faktor yang menyebabkan cepatnya kerusakan pada BLA

1. Faktor Pola Perawatan yang terdiri dari;

a) Perawatan mesin

Perawatan mesin akan mempengaruhi kondisi BLA, karena mesin yang terawat baik akan lebih mudah distarter sehingga mengurangi kerja BLA.

b) Penegecekan air Aki

Karena frekuensi pemberhentian, frekuensi starter dan penguapan air yang tinggi pada angkutan umum, maka sebaiknya pengecekan air aki dilakukan paling tidak seminggu sekali. Pada trayek yang diteliti mayoritas pengecekan air dilakukan sebulan sekali.

c) Pengecekan kelistrikan

Penegecekan kelistrikan sebaiknya dilakukan paling tidak 3 bulan sekali, diharapkan dengan kelistrikan yang baik beban rugi listrik pada BLA dapat dikurangi, sehingga memperpanjang usia BLA.

2. Faktor Pola Pemakaian yang terdiri dari;

a) Frekuensi hidup mati mesin Dapat menjadi sangat tinggi terutama pada saat mengantri diterminal.

b) Jumlah starter untuk menghidupkan mesin dingin

Jika dibutuhkan 3 kali starter untuk menghidupkan mesin dingin, maka harus dilakukan pengecekan mesin dan kondisi BLA. Pada trayek yang diteliti sekitar 35\% responden melakukan starter lebih dari 2 kali.

c) Penyesuaian Spesifikasi BLA pada Penambahan aksesoris sound sistem dan lampu.

3. Pada persepsi kepuasan terhadap kualitas BLA, sebagian besar responden menyatakan tidak puas terhadap kualitas merk-merk yang beredar dipasaran, meskipun dapat dikatakan merk tertentu memiliki tingkat kepuasan yang lebih tinggi dari merk lainnya.

\section{Saran}

1. Untuk memperpanjang usia pakai BLA, maka pemilik angkutan/sopir perlu menambahkan proses pengecekan air dengan jarak seminggu, pengecekan kelistrikan selama 3 bulan. sebagai bagian dari prediktive maintenance

2. Dalam kondisi mesin dingin apabila starter harus dilakukan lebih dari 2 kali maka, sebaiknya diberikan jeda 3-5 menit, hal ini akan sangat membantu dalam memperpanjang usia BLA

3. Penataan terminal yang lebih efisien, sehingga mengurangi kerugian bahan bakar serta BLA karena Frekuensi hidup mati mesin yang tinggi.

4. Perlunya desain ulang BLA untuk kebutuhan angkutan umum oleh produsen, sehingga bisa mengakomodasi karakteristik operasional angkot.

\section{DAFTAR PUSTAKA}

[1] B. Culpin, A.F. Hollenkamp, D.A,J. Rand "Pulsed current charging of lead acid battery- possible mean for overcome premature capacity loss?," J. Power Sources , Vol 38 63-74, 1992

[2] B. Culpin, A.F. Hollenkamp, D.A,J. Rand "Pulsed current charging of lead acid battery- possible mean for overcome premature capacity loss?," J. Power Sources , Vol 38 63-74, 1992

[3] D. Pavlov, "Lead Acid Batteries: Science and Technology", Elsevier, Amsterdam, p.21, 2011

[4] Paul Ruetschi "Energy storage and the environment: the role of battery echnology," Journal of Power Sources, Vol 127p.33-44, 2004

[5] Tatang M, Amirin, "Skala Likert: Penggunaan dan Analisis Datanya," p. 15, 2015 